\title{
A Comparative Study: NPA's in Indian Banking Industry
}

\author{
Dr Jai Prakash Tripathi ${ }^{1}$, Dr. Ravindra Kumar Kushwaha ${ }^{2}$, Mr Satish Mewada ${ }^{3}$ \\ ${ }^{I}$ Dean, MBA, Sri Satya Sai University of Technology \& Medical Sciences, Sehore, (MP), India. \\ ${ }^{2,3}$ Assistant Professor, MBA, Sri Satya Sai University of Technology \& Medical Sciences, Sehore, (MP), India
}

\begin{abstract}
The Indian managing an account framework has experienced huge change taking after monetary part changes. It is embracing global best practices with a dream to fortify the keeping money area. A few prudential and provisioning standards have been presented, and these are pressurizing banks to enhance productivity and trim down NPAs to enhance the monetary wellbeing in the keeping money framework. Out of sight of these improvements, this study endeavors to inspect the condition of issue of the Non-performing Assets (NPAs) of the general population area banks and private division banks in India with unique reference to weaker segments. The study depends on the auxiliary information recovered from Report on Trend and Progress of Banking in India. The extent of the study is constrained to the examination of NPAs of people in general segment banks and private part banks NPAs relating to just weaker segments for the period seven (7) years i.e. from 2004-2010. It looks at pattern of NPAs in weaker segments in both open segment and private segment banks. The information has been dissected by measurable apparatuses, for example, rates and Compound Annual Growth Rate (CAGR). The study watched that people in general area banks have accomplished a more noteworthy entrance contrasted with the private segment banks versus the weaker areas.
\end{abstract}

Keywords: old private sector banks, new private sector banks, credit risk.

\section{Introduction}

Managing an account industry is a noteworthy part of the economy that has accomplished recharged center after monetary segment changes and the passage of private area banks. This area is the establishment of cutting edge monetary advancement and linchpin of improvement methodology .It frames the center of the money related segment of an economy. Through assembly of assets and their better allotment, business banks assume an imperative part in the advancement procedure of immature nations. Business banks enhance the portion of assets by loaning cash to need part of the economy. These banks give a meeting ground to the savers and speculators among different pointers of monetary security, banks' non-performing advance expect basic significance since it thinks about the benefit quality, credit danger and effectiveness in the distribution of assets to gainful divisions. A typical point of view is that the issue of banks' non-performing credits is attributed to political, financial, social, innovative, lawful and natural. In present times, managing an account in India is genuinely developed as far as supply, item range and reach. Be that as it may, reach in rustic India still remains a test for people in general division and private area banks. The Reserve Bank of India is chiefly worried with giving account to weaker area of society, improvement of need areas and giving credit under differential rate of premium plan. After changes in 1991, the section of numerous private players has been allowed. Post progression request PSB's to rival very much enhanced and asset rich private Banks and to give fine supported administrations and remarkable items to suit clients need. PSB's have as of now relinquished a great deal of their benefits for accomplishment of social goals. Because of ferocious rivalry and innovation, the PSB's are intuition to enhance efficiency and gainfulness which is a key to get by in a globalized economy.

The eventual fate of PSB's future in light of their capacity to persistently assemble great quality resources in an inexorably aggressive environment and keeping up capital ampleness and stringent prudential standards. Combination and rivalry might be key components affecting the nationalized banks later on. Because of changes, it has been felt that there is a need to increment in benefits as well as diminishment in nonperforming resources (NPA's) of banks.It is in this setting the study has attempted an experimental investigation for assessing the non-performing advances of open division banks and private area saves money with extraordinary reference to weaker areas.

\section{Review of Literature}

There are various observational studies led on the issue of Non-performing Assets of business banks in India and also abroad. Present audit manages the experimental studies directed in Indian connection on Nonperforming Assets in weaker areas of open segment banks and private part banks. A portion of the striking studies in this field are as taking after Amandeep (1991) endeavored to gauge benefit and productivity of Indian Nationalized banks and to examine the effect of need division loaning, credit approaches, land development, modern infection, rivalry, store synthesis, foundation costs, auxiliary pay, spread and weight on bank 
gainfulness. For this reason, pattern examination, proportion investigation and relapse examination were utilized.

Swamy (2001) examined the relative execution of various bank bunches since 1995-96 to 1999-2000. An endeavor was made by scientist to recognize components which could have prompted changes in the position of individual banks as far as their offer in the general managing an account industry. He dissected the offer of rustic branches, normal branch size, patterns in bank's gainfulness, offer of open part resources, offer of wages in consumption, arrangement and possibilities, net non-execution resources in net advances, spread, has been ascertained. He inferred that in numerous regards nationalized open divisions banks much superior to anything private banks, even they are superior to anything outside banks.

Rituparna Das (2002) played out an examination on Managing the Risk of Non-Performing Assets in the Small Scale Industries in India. In this article the specialist tries to look for an answer for the issue of NPA in the little scale businesses under the current conditions of saving money and protection cooperating under the same rooftop. What is pushed in this article is the squeezing need of the little scale business visionary for getting to be mindful and instructed in current business administration holding an expert state of mind toward discerning basic leadership and banks need to encourage that procedure as a part of the credit strategy sold by them.

Prashanth K. Reddy (2002) in his examination paper on the subject, "A near investigation of Nonperforming Assets in India in the Global connection" analyzed the similitudes and dissimilarities, medicinal measures. Money related part change in India has advanced quickly on angles like loan cost deregulation, lessening for possible later use necessities, hindrances to passage, prudential standards and danger based supervision. The study uncovers that the shielding of feeble organizations while changing operational guidelines of the diversion is rolling out execution of operational improvements troublesome and inadequate. Changes required to handle the NPA issue would need to traverse the whole extent of legal, nation and the organization to be really powerful. This paper manages the encounters of other Asian nations in treatment of NPAs. It further investigates the impact of the changes on the level of NPAs and proposes systems to handle the issue by drawing on encounters from different nations.

Amitabh Joshi (2003) directed a review on "Examination of Non-Performing Assets of IFCI Ltd". The study found that Profitability and Viability of Development Financial Institutions are straightforwardly influenced by quality and execution of advances. The fundamental component of Sound NPA Management System is snappy recognizable proof of Non-performing progresses their control at least levels and guaranteeing that their impingement on the financials is at low level. Exorbitant dependence on Collaterals has driven Institutions to long drawn prosecutions and henceforth it ought not to be sole criteria for authorization. Banks ought to deal with their presentation breaking point to few borrower(s) and linkage should be placed with net owned funds for developing control over high leverages of borrower level. Concentrate additionally uncovered that trade of credit data among banks would be enormous help to them to maintain a strategic distance from conceivable NPAs. Administration Information framework and Market insight ought to be used to their maximum capacity.

Chandrashekhar and Ray (2005) demonstrate that open segment banks have progressively decided on interest in danger free returns of government securities, their offer altogether acquiring resources ascending from 26 to 33 percent amid the 1990s. This pattern has been turned around in the 21 st century. 27 But there is most likely authorization of stringent prudential standards, capital sufficiency stipulations, setting up of the Board for Financial Supervision (BFS) and weight to lessen NPAs have made banks so hazard unwilling that they have decreased their presentation to private advances with even an unobtrusive danger of non-recuperation.

TamalDattaChaudhuri (2005) analyzed the "Determination Strategies for Maximizing Value of NonPerforming Assets (NPAs)". The article shows that declining capital sufficiency antagonistically influences shareholder esteem and confines the capacity of the bank/foundation to get to the capital business sector for extra value to upgrade capital ampleness. In this way, if a determination technique for recuperation of duty from NPAs is not set up rapidly and effectively, these advantages would fall apart in worth after some time and little esteem would be acknowledged toward the end with the exception of might be its scrap esteem. The motivation behind this paper is to show the different contemplations that one needs to tolerate at the top of the priority list before focusing on a determination methodology and gives a State - Resolution - Mapping (SRM) system. Notwithstanding, the paper has not particularly examined about the different determination procedures that could be set up for recuperation from NPAs, and specifically, in which circumstance which kind of methodology ought to be embraced.

Isaac K. Otchere (2005) led a study on the execution of privatized banks in center and low-wage nations indicates blended results by "Aggressive and Value Effects of Bank Privatization in Developed Countries". The paper watched that private banks in created nations have encountered noteworthy enhancements in working execution. The change in execution stays critical subsequent to controlling for tirelessness in bank execution. A correlation of the execution of privatized banks in created and creating nations proposes that 
privatization has supported unnecessary danger taking among privatized banks in creating nations, with the result that those banks convey huge non-performing resources than their partners in the created nations. They likewise watch that reliable with the aggressive impacts theory, financial specialists view privatization declarations as portending terrible news for adversary banks.

Sathya (2005) analyzed the impact of privatization of banks on execution and productivity. The information taken was for a long time (1998-2002) and it was examined by utilizing contrast of means test. The saving money area in India incorporates household banks (exclusive, incompletely privatized banks, completely PSB's) and also outside banks, and goal of this study is to contemplate the effect of privatization on the managing an account firms. It was inferred that incompletely privatized banks have performed better when contrasted with completely PSB's in admiration of monetary execution and effectiveness. Halfway privatized banks have kept on demonstrating enhanced execution and proficiency in the year after privatization

Ved Pal and Malik (2007) in their experimental paper inspected the distinction in budgetary attributes of open, private and outside segment banks taking into account components, for example, benefit, liquidity, danger and productivity. Test of 74 Indian business banks comprising of 24 open segments, 24 private segment and 23 outside banks was taken for the time of 2000-2005. Multinomial relapse examination was utilized and comes about uncovered that outside banks turned out to be superior worker in creating business with a given level of assets and they are better furnished with administrative practices and as far as aptitudes and innovation. Outside banks were more predictable with business sector framework as reflected regarding net premium edge. People in general banks developed as the following best entertainer after remote banks. There were giving a higher profit for value in contrast with remote and private banks. It was superior worker in streamlining their costs which was reflected from cost rate and productivity proportion. The private area banks rose with a superior utilization of assets when contrasted with PSB's.

Thomas P. Ferguson (2007) directed an examination on "Perceptions on the Securitization of NonPerforming Loans in Russia". Resource securitization is a thriving pattern in Russia as organizations loaded by poor FICO scores look for access to capital at lower costs than they would be permitted in conventional value or obligation markets. Study shows that securitization of these terrible credits have not happened in Russia at the levels one may anticipate. This has been because of both a generally little measure of credits that fail to meet expectations and in addition lawful and administrative obstacles that have debilitated speculators and banks alike. The study has been directed to look at the extension of buyer credit in Russia and the conditions under which it is happening show that the level of non-performing advances is because of quickly increment and as the method of reasoning for keeping up the obstacles that obstruct securitizing these advances is being reconsidered, those hindrances are being downsized to clear a path for business sector members to take part in such securitizations. Hence, this article suspects a noteworthy ascent in the level of non-performing credits, which will be sensibly combined with an expanded enthusiasm of Russian moneylenders in securitizing these advantages.

UshaArora, BhavnaVashisht and Monica Bansal (2009) in the exploration on "An Analytical Study of Growth of Credit Schemes of Selected Banks" investigated and thought about the execution (as far as advance dispensing and non-performing resources) of credit plans of chose banks throughout the previous five years. This paper is isolated into two sections. In the initial segment, bank-wise and also year-wise examinations are finished with the assistance of Compound Annual Growth Rate (CAGR), mean and standard deviation; and in the second section, a positive relationship is found between aggregate advance dispensing and aggregate NPA $\mathrm{O} / \mathrm{S}$ of chose keeps money with the assistance of a connection procedure. The study found a positive relationship between aggregate advance payment and aggregate Non-Performing Assets Outstanding (NPA O/S) of chose banks.

There are numerous studies that have measured the productivity of banks the world over notwithstanding, not very many studies have assessed the execution of Indian banks. The brief survey of the writing is utilized to define hypothetical investigation of non-performing credits attempted in the present study. This study is intended for breaking down Nonperforming Assets in weaker segments of open segment banks and private segment banks in India.

\section{Objectives of Study}

The present study is based upon the full scale way to deal with dissect Nonperforming Assets in weaker areas of open division banks and private segment banks particularly the targets of the study are:

- To study Comparison between Nationalized banks and State bank Group NPAs relating to weaker area

- To examine the Comparison between Old private part banks and New private area banks NPAs relating to weaker segments

- To decide the Non-performing Assets in weaker areas of private part banks and open division banks

- To inspect the Share of Nationalized banks and State Bank Group in the Total PublicPart Banks Advances and NPAs relating to weaker Sections 
- $\quad$ Evaluate the Share of Old Private Sector NPAs and New Private Sector NPAs in the aggregate private part Advances and NPAs relating to Weaker Sections.

\section{Research Methodology}

The study is investigative in nature, and the present study utilizes the most recent accessible distributed auxiliary information for the years 2004-2010 incorporated from Report on Trends and Progress of Banking in India, 2004-10 .The extent of the study is restricted to seven years information. The information has been investigated utilizing rate technique. The study is identified with Public area banks and private division banks which incorporates nationalized banks and State Bank of India (SBI) and its partners if there should be an occurrence of open segment banks and in the event of private segment banks it incorporates both old and private segment banks and new private segment banks.

\section{Analysis And Results}

It is apparent from table 1 that advances of the banks have shown a rising trend since 2003-04 to 2009 $-r$ 2010. The study found that the Nationalized banks advances and state bank group advances CAGR stood at 26.19 and 21.16 respectively and the NPAs CAGR showed a decline trend of -2.71 in case of Nationalized banks and -6.13 in case of state bank group.

Table 1. Comparison between banks and state bank group

\begin{tabular}{|c|c|c|c|c|c|c|}
\hline & & & & & & (Amount in Rs. Crores) \\
\hline & \multicolumn{2}{|c|}{ Nationalized Banks } & & & & \\
\hline & & & Percentage of & State Bank Group & & Percentage of \\
\hline years & Advances & NPAs & NPAs & Advances & NPAs & NPAs \\
\hline 2004 & 23612.63 & 4082.56 & 17.29 & 11880.03 & 2623.93 & 22.08 \\
\hline 2005 & 30.804 .05 & $2,880.71$ & 9.35 & $20,640.78$ & $2,871.33$ & 13.91 \\
\hline 2006 & $39,807.43$ & $3,250.59$ & 8.17 & $19,663.59$ & $1,772.63$ & 9.01 \\
\hline 2007 & $51,599.75$ & $3,456.75$ & 6.7 & $27,244.93$ & $1,724.40$ & 6.33 \\
\hline 2008 & $63,078.89$ & $3,330.00$ & 5.28 & $36,914.99$ & $1,975.37$ & 5.35 \\
\hline 2009 & 85,923 & 3,784 & 4.4 & 36,971 & 1,290 & 3.5 \\
\hline 120285.71 & 3,368 & 2.8 & 45540.54 & 1,685 & 3.7 & \\
\hline CAGR & 26.19 & $\frac{1}{-2.71}$ & $\frac{1}{-22.91}$ & 21.16 & -6.13 & -22.53 \\
\hline
\end{tabular}

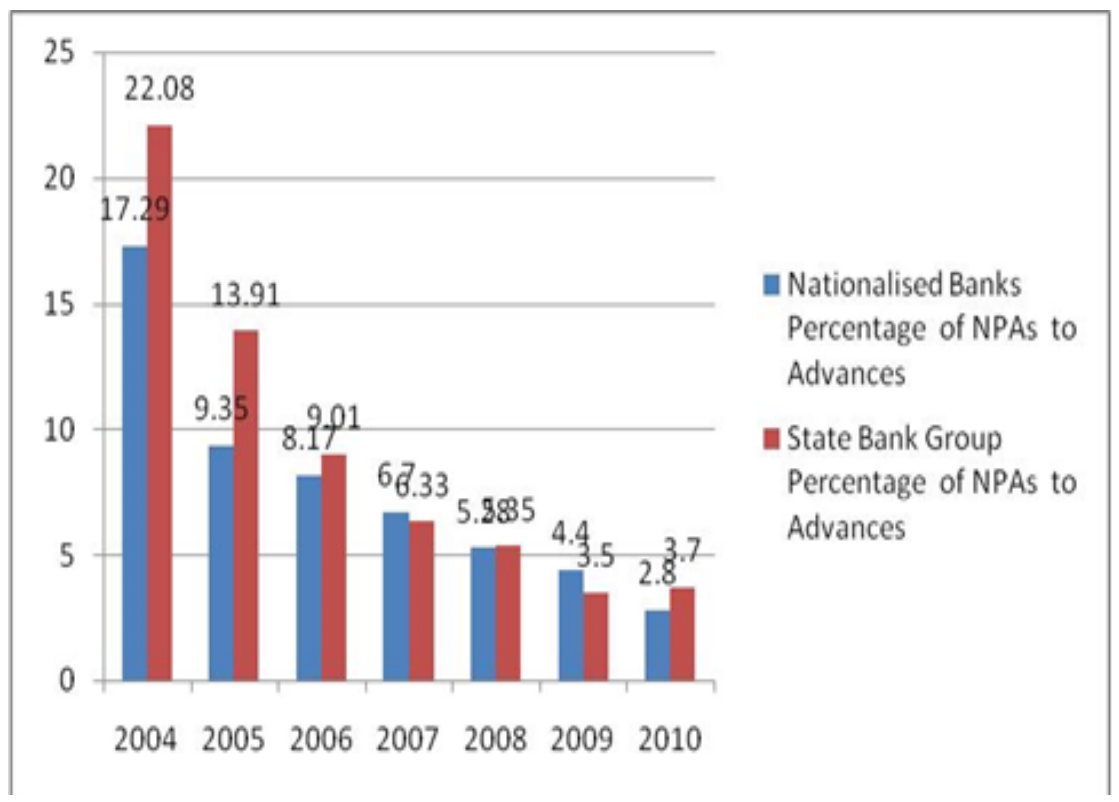

Figure 1. Comparison between Nationalized banks and State bank Group percentage of NPAs pertaining to weaker sections 
Table 2. Comparison between Old private sector banks and new private sector banks $\%$ of NPAs pertaining to weaker sections

\begin{tabular}{lllllll}
\hline & Old Private Sector Banks & \multicolumn{7}{c}{ New Private Sector Banks } & & \\
\hline years & Advances & NPAs & $\%$ of NPAs & Advances & NPAs of NPAs \\
\hline 2004 & 1228.4 & 155.47 & 12.66 & 51.46 & 0.05 & 10.29 \\
\hline 2005 & 1501.62 & 207.97 & 13.85 & 79.75 & 0.01 & 0.01 \\
\hline 2006 & $2,366.10$ & 267.26 & 11.3 & 56.6 .24 & 8.93 & 1.58 \\
\hline 2007 & $2,416.93$ & 149.3 & 6.18 & $1,445.25$ & 0.01 & 0.01 \\
\hline 2008 & $3,305.40$ & 116.79 & 3.53 & $1,726.17$ & 0.25 & 0.01 \\
2009 & 5,538 & 77 & 1.4 & 9,514 & 14 & 0.1 \\
\hline 2010 & 9800 & 98 & 1.0 & 16000 & 32 & 0.2 \\
CAGR & 34.54 & -6.38 & -30.42 & 127.04 & 151.7 & -43.05
\end{tabular}

Source: Report on Trend and Progress of Banking in India 2004 - 2010

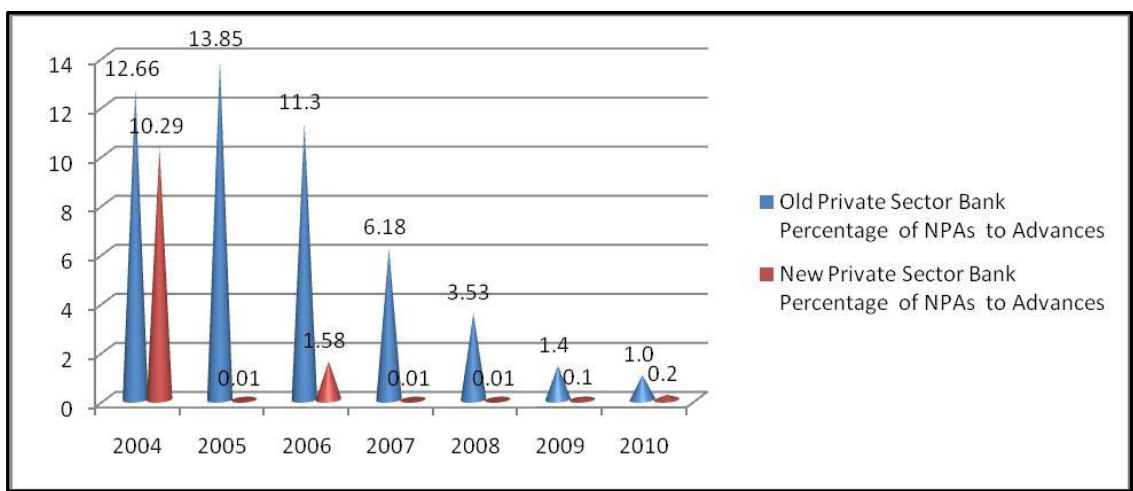

Figure 2.Comparison between Old private sector banks and new private sector banks \% of NPAs pertaining to weaker sections

The study watched that the CAGR in advances and NPAs of old private segment banks is 34.54 and 6.38 though on account of New private area banks It found that the CAGR in the event of advances is 127.04 and NPAs is 151.7 which is high when contrasted with old private part banks. There was a blend pattern in the event of new private part banks NPAs i.e. from 2003-2004 to $2004-2005$ the NPAs lessened in outright terms and in rate terms however in the year 20052006 the NPAs expanded in both the terms i.e in supreme terms and in rate terms, again amid the year 2007 it diminished to 0.01 in both total terms and also in rate terms. Later on, from the year 2008 to 2010 the NPAs expanded in both the terms i.e in total terms and in addition in rate terms It is watched that regardless of increment in nonperforming resources (NPAs) in outright terms amid the year, resource nature of new private division banks enhanced in the previous couple of years as reflected in the decrease in the proportion i.e. NPAs as rate of advances, Hence, it can be expressed that overall there is change in the advantage nature of new private segment banks.

Table 3. Comparison between public sector banks and private sector banks NPAs pertaining to weaker sections

(Amount in Rs. Crores)

\begin{tabular}{|c|c|c|c|c|c|c|}
\hline \multirow[b]{2}{*}{ years } & \multicolumn{3}{|c|}{ Public Sector Banks } & \multicolumn{3}{|c|}{ Private Sector Banks } \\
\hline & Advances & NPAs & $\%$ of NPAs & Advances & NPAs & $\%$ of NPAs \\
\hline 2004 & $35,492.66$ & $6,706.49$ & 18.9 & 1279.86 & 155.52 & 12.15 \\
\hline 2005 & $51,444.83$ & $5,752.04$ & 11.18 & 1581.37 & 207.98 & 13.15 \\
\hline 2006 & $59,471.02$ & $5,023.22$ & 8.45 & $2,932.34$ & 276.19 & 9.43 \\
\hline 2007 & $78,844.69$ & $5,181.15$ & 6.57 & $3,862.18$ & 149.31 & 3.87 \\
\hline 2008 & $99,993.88$ & $5,388.00$ & 5.39 & $5,031.57$ & 117.04 & 2.33 \\
\hline 2009 & $1,22,894$ & 5,074 & 4.1 & 15,052 & 91 & 0.6 \\
\hline 2010 & 165826.2 & 5,053 & 3.0 & 25800 & 130 & 0.5 \\
\hline
\end{tabular}

Source: Report on Trend and Progress of Banking in India $2004-2010$ 


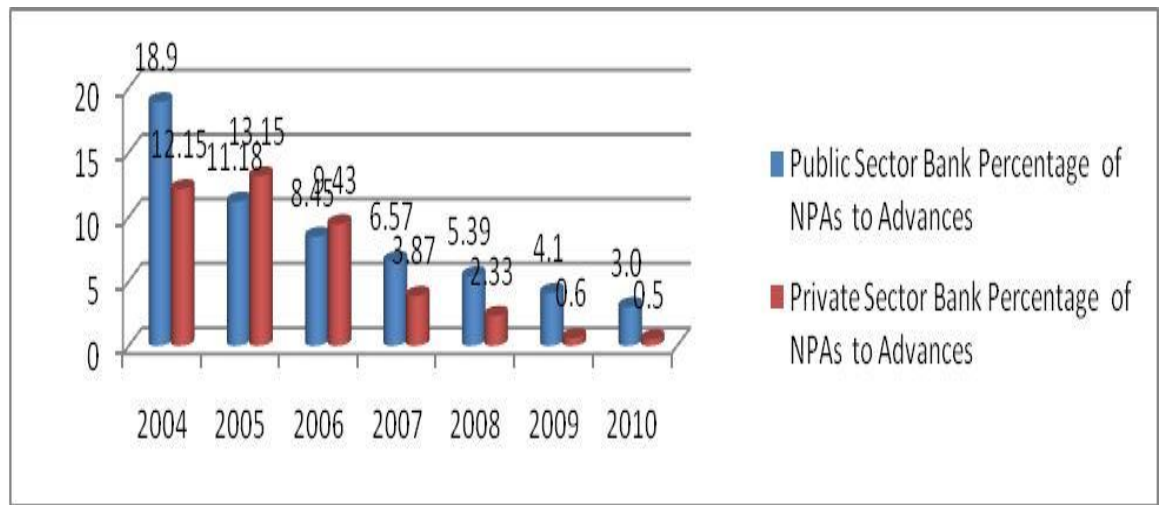

Figure 3. Comparison between public sector banks and private sector banks NPAs pertaining to weaker sections

The above study inspects that accomplishments of the private area banks in the event of advances to weaker areas are as low when contrasted with that of open part banks Advances of people in general division banks in total term have expanded from Rs 35492.66 crores in 2003-04 to Rs 165826.2 crore in 2009-10. Furthermore, that of private division banks expanded from Rs1279.86 crores in 2003-04 to Rs25800 crores in 2009-10. The NPAs of general society segment banks in supreme terms have diminished from Rs 6706.49 crores in2003-04, to Rs 5053 crores and on account of the private division banks it has diminished from Rs 155.52 crores in 2003-2004 to Rs130 crores in 2009-2010. The NPAs in supreme terms have diminished by $24.66 \%$ percent in broad daylight segment banks and $16.41 \%$ in private area banks in the year 2009-10 more than 2002-03. .The NPA proportion for weaker segments for open division banks was higher at 3.0 for every penny than 0.5 for every penny for private segment banks at end-March 2010.

Table 4. Share of Nationalized banks and State Bank Group in the Total Public Sector Banks Advances and NPAs pertaining to weaker Sections

\begin{tabular}{|l|l|l|l|l|l|l|}
\hline & Nationalized Banks & & State Bank Group & & Public Sector Banks & \\
\hline & & & & & & \\
\hline Years & Advances & NPAs & Advances & NPAs & Advances \\
\hline & & & & & & \\
\hline 2004 & $23612.63(66.53)$ & $4082.56(60.87)$ & $11880.03(33.47)$ & $2623.93(39.13)$ & $35492.66(100)$ & \\
\hline & & & & & & \\
\hline 2005 & $30.804 .05(59.88)$ & $2880.71(50.08)$ & $20640.78(40.12)$ & $2871.33(49.92)$ & $51444.83(100)$ & $5706.49(100)$ \\
\hline & & & & & & \\
\hline 2006 & $39807.43((66.94)$ & $3250.59(64.71)$ & $19663.59(33.06)$ & $1772.63(35.29)$ & $59471.02(100)$ & $5023.22(100)$ \\
\hline & & & & & & \\
\hline 2007 & $51599.75(65.44)$ & $3456.75(66.72)$ & $27244.93(34.56)$ & $1724.4(33.28)$ & $78844.69(100)$ & $5181.15(100)$ \\
\hline & & & & & & \\
\hline 2008 & $63078.89(63.08)$ & $3329.72(61.80)$ & $36914.99(36.92)$ & $2058.41(38.20)$ & $99993.88(100)$ & $5388.13(100)$ \\
\hline & & & & & & \\
\hline 2009 & $85923(70)$ & $3784(75)$ & $36971(30)$ & $1290(25)$ & $1,22,894(100)$ & $5074(100)$ \\
\hline & & & & & & \\
\hline 2010 & $120285.71(72.54)$ & $3368(67)$ & $45540.54(27.46)$ & $1685(33)$ & $165826.24(100)$ \\
\hline
\end{tabular}

Source: Report on Trend and Progress of Banking in India $2004-2010$

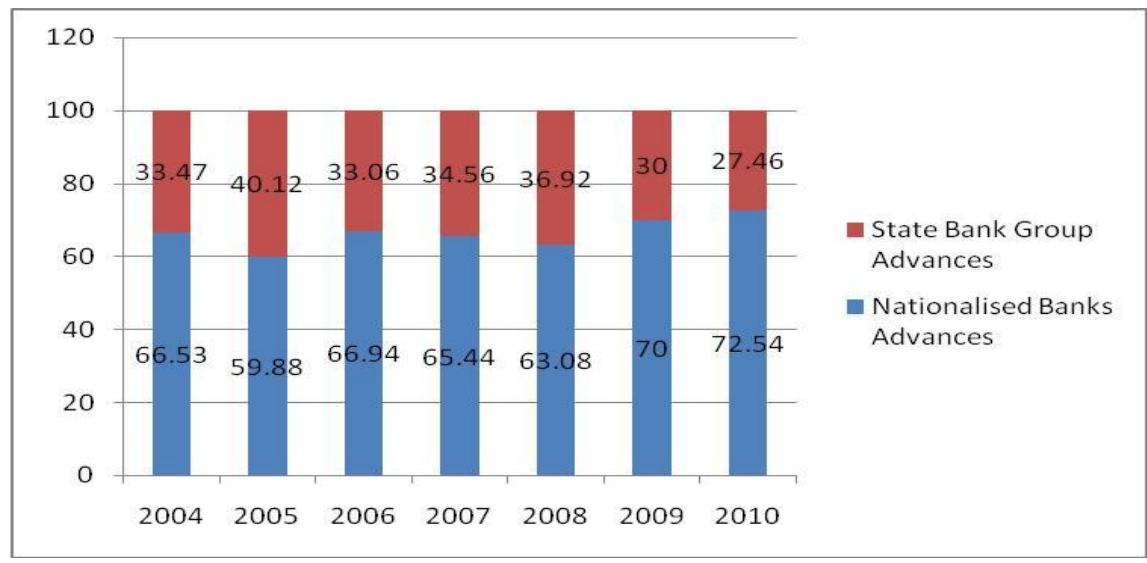

Figure 4 A. Share of Nationalized banks and State Bank Group in the Total Public Sector Banks Advances pertaining to weaker Sections. 
Figure 4 B. Share of Nationalized banks and State Bank Group in the Total Public Sector Banks NPAs pertaining to weaker Sections

Over the period of study the share of nationalized banks in advances and NPAs ismore than the state bank group advances and NPAs.

Table 5. Share of Old Private Sector banks NPAs and New Private Sector banks NPAs in the total private sector Advances and NPAs pertaining to Weaker Sections

(Amount in Rs. Crore)

\begin{tabular}{|c|c|c|c|c|c|c|}
\hline & \begin{tabular}{lc|} 
& Privat \\
Old & e \\
Sector & Banks
\end{tabular} & & $\begin{array}{l}\text { New Private } \\
\text { Sector Banks }\end{array}$ & & \begin{tabular}{|l} 
Private \\
Sector \\
Banks \\
\end{tabular} & \\
\hline Year & $\begin{array}{l}\text { Advance } \\
\text { s }\end{array}$ & NPAs & $\begin{array}{l}\text { Advanc } \\
\text { es }\end{array}$ & NPAs & Advances & NPAs \\
\hline 2004 & $1228.4(95.98)$ & $155.47(99.97)$ & $51.46(4.02)$ & $0.05(0.03)$ & \begin{tabular}{|l|}
$1279.86(100)$ \\
\end{tabular} & $155.52(100)$ \\
\hline \multirow{3}{*}{2005} & & & & & 1581.37(100 & \\
\hline & $1501.62(94.96)$ & 207.97(99.98) & $79.75(5.04)$ & $0.01(0.02)$ & ) & $207.98(100)$ \\
\hline & $2366.1(80.69)$ & $267.26(96.77)$ & $566.24(19.31)$ & $8.93(3.23)$ & $\begin{array}{l}2932.34(100 \\
)\end{array}$ & $276.19(100)$ \\
\hline 2006 & $\begin{array}{l}2416.93((62.58 \\
)\end{array}$ & $149.3((99.99)$ & $1445.25(37.42$ & $0.01(0.01)$ & $\begin{array}{l}3862.18(100 \\
)\end{array}$ & $149.31(100)$ \\
\hline 2008 & $3305.4(65.69)$ & $\begin{array}{l}116.79((99.79 \\
)\end{array}$ & $\begin{array}{l}1726.17(34.31 \\
)\end{array}$ & $0.25((0.21)$ & $\begin{array}{l}5031.57(100 \\
)\end{array}$ & $117.04(100)$ \\
\hline 2009 & $5538(36.79)$ & $77(84.62)$ & 9514(63.21) & $14(15.38)$ & $15052(100)$ & 91(100) \\
\hline 2010 & 9800(37.98) & $98((75.38)$ & $16000(62.02)$ & $32(24.62)$ & $25800(100)$ & $130(100)$ \\
\hline
\end{tabular}

Source: Report on Trend and Progress of Banking in India 2004 - 2010

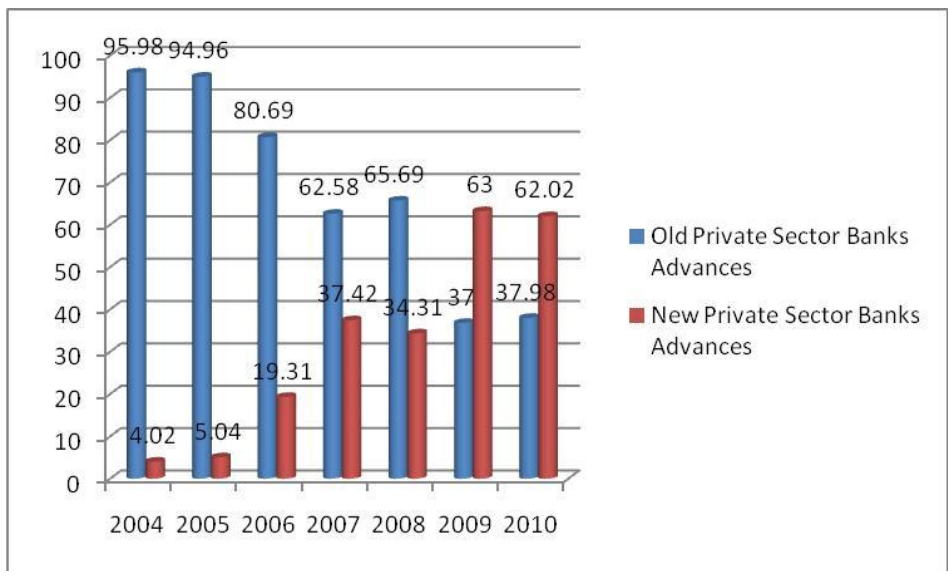

Figure 5 A. Share of Old Private Sector and New Private Sector Advances in the total private sector Advances pertaining to Weaker Sections

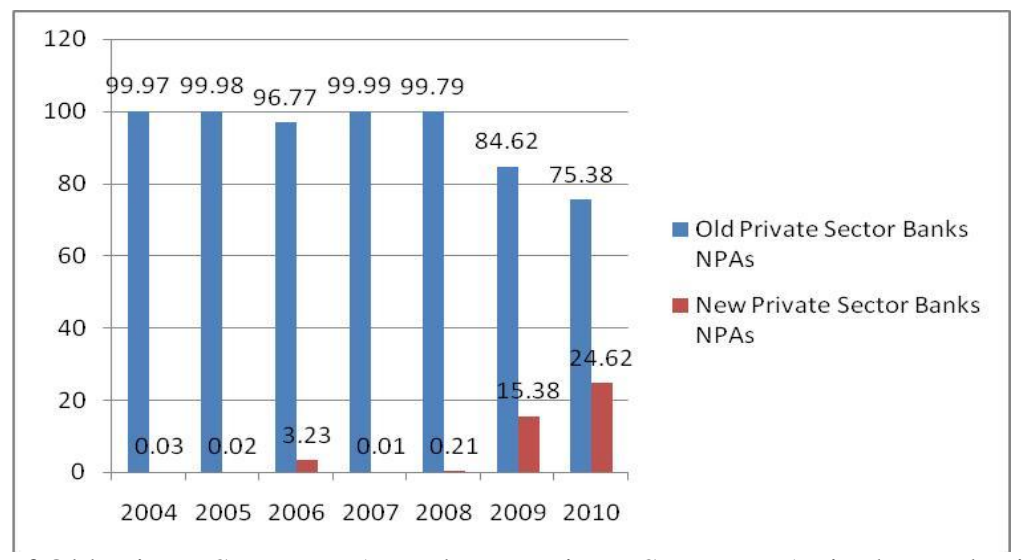

Figure 5 B. Share of Old Private Sector NPAs and New Private Sector NPAs in the total private sector NPAs pertaining to Weaker Sections 
The study researched the break astute examination of private division banks which contains both old private segment banks and new private part banks. This break insightful examination shows that amid the time of the study in the event of advances and NPAs the offer of old private area banks over new private part banks is more till the year 2008 from there on from the year 2009 the situation has changed that is on account of advances the offer of new private segment banks is more than old private division banks yet where as for the situation NPAs the offer of old private segment banks is more than new private segment banks.

\section{Findings}

It is found on the premise of examination of information that the advantage nature of open part banks and private segment banks enhanced reliably in the previous couple of years as reflected in the decrease in the proportion i.e. NPAs as rate of advances to weaker areas from $18.9 \%$ to 3 percent if there should be an occurrence of open part banks and from 12.15 percent to 0.5 percent

Over the time of study, it has been enlisted that the general population area banks have accomplished a more noteworthy entrance contrasted with the private segment banks versus the weaker segments. The outcomes from above examination demonstrate that there is solid proof that the insights in the advances to the weaker area of new private segment miniscule.

\section{VII.Conclusions}

The study watched that there is increment in advances over the time of the study. Be that as it may, the decrease in proportion of NPAs demonstrates change in the benefit nature of Indian open division banks and private segment banks. It is found on the premise of examination that there is noteworthy change in the administration of nonperforming resources of the general population part banks in India. The concentrate at long last watches that the prudential and provisioning standards and different activities taken by the administrative bodies has pressurized banks to enhance their execution, and therefore came about into trim down of NPA and also change in the money related wellbeing of the Indian saving money framework.

It has been watched that the keeping money area in India has reacted emphatically in the field of improving the part of business sector powers with respect to measures of prudential controls of bookkeeping, wage acknowledgment, provisioning and presentation, presentation of CAMELS supervisory rating framework and lessening of NPA's and up degree of innovation. Be that as it may, in the meantime changes neglected to carry keeping money framework at a standard with universal level and still the Indian managing an account segment is for the most part controlled by government as PSB's being pioneers in this circle. It is recommended that administration ought to define bank particular strategies and ought to actualize these arrangements through Reserve Bank of India for upliftment of Public Sector Banks

.Open part banks ought to attempt to update innovation and ought to plan client benevolent approaches to face rivalry at national and global level.

\section{References}

[1] Arora, U., Vashisht, B. and Bansal, M. (2009), An Analytical Study of Growth of Credit Schemes of Selected Banks (March 26, 2009). The Icfai UniversityJournal of Services Marketing, Vol. VII, No. 1, pp. 51-65, March 2009.

[2] Bhasin, N. (2008), Banking Developments in India 1947to 2007, New Delhi, Century Publications.

[3] Chhimpa, J. (2002), Incremental NPA: Stem that Inflow, Vinimaya, 23(3): 18-21.

[4] Chopra, K. (2005), Managing Profitability andProductivity in Public Sector Banking, ABS publications,Jalandhar.

[5] Desai,V. (2007), Indian Banking-Nature and Problems, Himalaya Publishing House, Bombay.

[6] Gujral, N. (2003), NPA Blues and the Securitization Act, Vinimaya, 24(1): 13-23.

[7] Janki, B. (2002), Unleashing employ productivity; A need for a paradigm shift. Indian Banking association bulletin, XXIV (3): 7-9.

[8] Kaveri, V. S. (2001). Prevention of NPA Suggested Strategies, Vinimaya, 23(8): 7-9.

[9] Malyadri P. (2003), NPA's in Commercial Banks-An Overview, Banking Finance, Monthly, January 2003, Vol. XVI, pp.6-9.

[10] MilindSathya (2005), Privatization, Performance, and Efficiency: A study of Indian Banks, Vikalpa (1):23-28.

[11] Mukherjee, A, Nath, P \& Pal, MN (2002), Performance Benchmarking and Strategic Homogeneity of Indian Banks, International Journal of Bank Marketing, 20(3), pp: 122-139.

[12] Narasimham, M.S. \&Thampy, A. (2002), Activity Based Costing in Banking Service: A Case Study of a Large Indian Private Sector Bank, Prajnan, 31(2): 95-110.

[13] Pal Ved\& Malik N.S. (2007), A Multivariate Analysis of the financial characteristics of Commercial Banks in India. The Icfai Journal of Bank Management .VI (3).

[14] Prasad M., Sinha, K. K. and Prasad, K. M. (2004), Post-reform Performance of Public Sector Banks with Special Reference to Nonperformance Assets, Edited BookBanking in the New Millennium, New Delhi.

[15] Samal, B. (2002), The NPA Overhung: Magnitude, Solution and Legal Reforms, Vinimaya, 23 (3): 12-17.

[16] Swamy, B.N.A.2001, New Competition, Deregulation and Emerging Changes in Indian Banking. Bank Quest the Journal of Indian Institute of Bankers, 729(3): 3-22.

[17] Vashist, A. K. (2004), Commercial Banking in the Globalized Environment, Political Journal of India, 13(2): 1-10. 